\title{
Phytochemical and antioxidant properties of some Nigerian medicinal plants
}

\section{Olajide Olutayo, Idowu Doyinsola, Okolo Simon, Orishadipe Abayomi and Sunday Thomas}

\author{
Chemistry Advanced Laboratory, Sheda Science and Technology Complex (SHESTCO), P. \\ M. B. 186 GarkiPO Sheda - Abuja, FCT, Nigeria.
}

\begin{abstract}
Medicinal plants are of great importance to the health of individuals and communities. The medicinal value of these plants lies in some chemical substances that produce a definite physiological action on the human body. The most important of these are alkaloids, tannins, glycoside, saponins, steroids, terpenoids, flavonoids, phlobatannins, resins, balsam, volatile oils and cardiac glycosides. The distribution of these moieties in six medicinal plants extracts belonging to different families were assessed and compared. The radical scavenging activities of the plant extracts against 2, 2 - Diphenyl -1- picrylhydrazyl radical (DPPH) (Sigma - Aldrich) were determined by UV spectrophotometer at $517 \mathrm{~nm}$. Also, the significance of the plants in traditional medicine and importance of the distribution of these chemicals constituents were discussed with respect to the role of these plants in ethno medicinal usage in Nigeria.
\end{abstract}

Key words: Entandrophragma angolense, Anogeissus leiocarpus, Pavetta crassipes, Khaya senegalensis, Antioxidants, DPPH, Free radicals.

\section{INTRODUCTION}

Traditional knowledge of medicinal plants has always guided the search for new cures. In spite of the advent of modern high throughput drug discovery and screening techniques, traditional knowledge systems have given clues to the discovery of valuable drugs (Buenz et. al; 2004). Traditional medicinal plants are often cheaper, locally available and easily consumable, raw or as simple medicinal preparations. Nowadays, traditional medicinal practices form an integral part of complementary or alternative medicines. Although their efficacy and mechanism of action have not been tested scientifically in most cases, these simple medicinal preparations often mediate beneficial responses due to their active chemical constituents (Park and Pezzutto, 2002).

Free radicals, produced as a result of normal biochemical reactions in the body, are implicated in contributing to cancer, atherosclerosis, aging, immunosuppression, inflammation, ischemic heart disease, diabetes, hair loss and neurodegenerative disorders such as Alzheimer's disease and Parkinson's disease (Beal, 1995; Maxwell, 1995; Poulson, Preime, and Loft, 1998). The human body possesses innate defence mechanisms to counter free radicals in the form of enzymes such as superoxides dismutate, catalase, and glutathione peroxidase. Vitamin $\mathrm{C}$, vitamin $\mathrm{E}$, selenium, $\beta$ carotene, lycopene, lutein and other carotenoids have been used as supplementary antioxidants. Apart from these, plant secondary metabolites such as flavonoids and terpenoids play important role in the defence against free radicals (Devasagayan and Sainis, 2002; Park \& Pezzutto, 2002; Govindarajan, Vijayakumar \& Pushpangadan, 2005). Medicinal plant parts are commonly rich in phenolic compounds such as flavonoids, stillbenes, tannins, coumarins, lignans and lignins (Larson, 1988; Kahkomen et. al.; 1999). There have been several studies on the antioxidant activities of various herbs/plants with medicinal values. The present study aims to investigate the free radical scavenging activities and phytochemical constituents of some of the commonly used medicinal plants in South-western Nigeria.

The following plants were selected for investigation: Entandrophragma angolense welw. (Meliaceae), Khaya senegalensis Desr. (Meliaceae),Anogeissus leiocarpus DC.(Combretaceae), Pavetta crassipes K.Schum (Rubiaceae) and Abrus precatorius Linn.(Leguminosaceae). The extracts of the stem wood and root wood of E.angolense,stem-bark of K.senegalensis and extracts of the leaves of $P$. 
crassipes, $A$. precatorius and $A$. leiocarpus are commonly used in the traditional treatment of various diseases in South-western Nigeria.

For example,E.angolense is used in Ivory coast where its bark is pulped with salt and the seeds of Afromomum meleguata pepper, boiled in water which is drunk as a febrifuge. The bark also has analgesic properties to counter stomach and kidney pains, for ear ache and ophthalmias, and in external embrocation for rheumatism, muscular and arthritic pain (Burkill,1982).

K.senegalensis has flowers which are sometimes used medicinally for stomach-complaints and as an ingredient of anti-syphilitic prescriptions. Honey derived from its flowers is bitter and a bitter principle named as Cailcedrin has been isolated from it. Though its bark is also bitter and has a widely-held reputation as a fever-remedy. As a substitute for quinine, it has become known as 'quinine of Senegal.' Young twigs are used in Sudan as toothbrushes, peeled stem or the root is used by Hausas in Northern Nigeria as chew-sticks (Burkill, 1982).

A.leiocarpus leaves are rich in tannin, a decoction of leaves is applied to the skin in Ivory Coast to alter the pigmentation, and is used as an eye-wash for certain complaints. In some regions of Upper Guinea, the bark is used as a febrifuge in hot lotions and infusions, and in Ivory Coast prescriptions of leaves and bark with other drug-plants are taken for leprosy (Burkill, 1982).

A.precatorius leaves are used for anti-suppurative properties. They are ground with lime and applied on acne sores, boils and abscesses. The plant is also traditionally used to treat tetanus and to prevent rabies. Various African tribes use powdered seeds as oral contraceptives. It is also used in some traditional medicine to treat scratches and sores, and wounds caused by dogs, cats and mice (Watt and Breyer, 1962).

P.crassipes leaves are rich in nutrients, (Carbohydrates $62 \%$, Protein $15 \%$, and with a range of amino-acids most especially Aspartic acid, Glutamic acid and Leucine). Therefore, the leaves are dried and eaten after powdering and cooking with other foods or they may be boiled in slightly fermented water in which cereals have been left to steep and mixed with the pap. Dried leaves are used externally in Senegal as a powder dressing on syphilitic chancres. The leaf is used in Malawi as an anti-malarial and as part of a gonorrhoea treatment (Burkill, 1982).

\section{MATERIALS AND METHODS}

Collection and identification of plant materials: Fresh root wood and stem bark of E.angolense, A.precatorius were collected from Owo Ondo State Nigeria; whereas the leaves of K.senegalensis, A.leiocarpus and P.crassipes were collected from the vicinity of National Institute for Pharmaceutical Research and Development (NIPRD), Idu Industrial Area Abuja, Nigeria. The plants were identified by the Taxonomist at the Institute (NIPRD).

Extraction of plant materials: The plant materials (leaves of K.senegalensis, P.crassipes, A.leiocarpus,A.precatorius and the stem bark and root wood of E.angolense) were air-dried at room temperature $25^{\circ} \mathrm{C}$ for two weeks, after which they were grinded to a uniform powder. The methanol extracts were obtained by macerating the powdered samples $100 \mathrm{~g}$ of each of the dry powdered plant materials in $700 \mathrm{ml}$ of $70 \%$ aqueous methanol. The extracts were concentrated using a rotary evaporator under vacuum with the water bath set at $45^{\circ} \mathrm{C}$.

Phytochemical Screening: Phytochemical screening was performed using standard procedures (Trease et.al., 1989).

Determination of Antioxidant Activity: The radical scavenging activities of the plant extracts against 2 , 2-Diphenyl-1-picryl hydrazyl radical (Sigma-Aldrich) were determined by UV spectrophotometer at 517 $\mathrm{nm}$. Radical scavenging activity was measured by a slightly modified method previously described (BrandWilliams et. al, 1995 and Ayoola et.al., 2006). The following concentrations of the extracts were prepared, $0.05,0.1,0.5,1.0,2.0$, and $5.0 \mathrm{mg} / \mathrm{ml}$ in methanol (Analar grade). Vitamins $C$ was used as the antioxidant standard at concentrations of $0.02,0.05$, $0.1,0.2,0.5$ and $0.75 \mathrm{mg} / \mathrm{ml}$. $1 \mathrm{ml}$ of the extract was placed in a test tube, and $3 \mathrm{ml}$ of methanol was added followed by $0.5 \mathrm{ml}$ of $1 \mathrm{mM}$ DPPH in methanol. A blank solution was prepared containing the same amount of methanol and DPPH. The radical scavenging activity was calculated using the following formula:

$\%$ inhibition $=\left[\left\{A_{b}-A_{a}\right\} / A_{b}\right] \times 100$

Where $A_{b}$ is the absorption of the blank sample (without the extract) and $A_{a}$ is the absorption of the of the extract. 


\section{RESULTS AND DISCUSSION}

Phytochemical screening of plant materials: The various extracts screened showed the absence of alkaloids, phenols, resins, flavonoids, anthraquinones and cardiac glycosides. All the plant extracts showed the presence of tannins except A.precatorius which tested negative (Table 1). It confirmed what has been reported according to ( Burkill, 1982).Only P.crassipes tested negative for the presence of terpenoids.

Radical scavenging (anti-oxidant) assay exhibited $\mathrm{IC}_{50}$ of $1.28,2.34,3.74,0.60,2.18,2.94$ and 0.14 $\mathrm{mg} / \mathrm{ml}$ for E.angolense (RW) ,E.angolense (SW), K.senegalensis, P.crassipes, A.leiocarpus, A.precatorius and Vitamin $C$ respectively (Table 2 ). In the root wood and stem wood of E.angolense, antioxidant effects are dose related and decreases as concentration increases, although $I_{50}$ is above 1 $\mathrm{mg} / \mathrm{ml}$ extract seems to possess higher anti -oxidant capacity at lower concentration $(81.34 \%$ at 0.05 $\mathrm{mg} / \mathrm{ml}$ ). Also, P.crassipes, A.leiocarpus, $K$ .senegalensis are dose-dependent except A.precatorius which gave very poor result at lower concentration. A.leiocarpus was the most active antioxidant. As evident from the Table 2, there was noticeable variability in the anti oxidant activity of these plant extracts. Out of the five plants
screened,E.angolense, K.senegalensis, and $A$. leiocarpus were found to be good radical scavengers with the percent inhibition of 81.34, 84.0280 .38 and 89.02 at $0.05 \mathrm{mg} / \mathrm{ml}$ respectively whereas the percent inhibition for Ascorbic acid was 90.19 at $0.05 \mathrm{mg} / \mathrm{ml}$ which was used as a standard.

Tannins play important role in promoting wound healing. This could be the reason why the E.angolense is applied on wound portion of the body to give relief from pain (Table 1). Tannins are a major group of compounds that act as primary antioxidant or free radical scavengers (Polterait, 1997). The phenolic compounds in herbs act as antioxidants due to their redox properties, allowing them to act as reducing agents, hydrogen donors, free radical quenchers and metal chelators (Javanraedi et.al;2003). Owing to the complexity of the antioxidant materials and their mechanism of actions, it is obvious that no single testing method is capable of providing a comprehensive picture of the antioxidant profile of a studied sample and a combination of different methods is necessary. Despite such limitations, DPPH free radical scavenging assay can be helpful for preliminary screening and finding of novel antioxidant.

Table 1: Phytochemical screening results

\begin{tabular}{|l|l|l|l|l|l|l|}
\hline Test & $\begin{array}{l}\text { E.Angolense( } \\
\text { Root wood) }\end{array}$ & $\begin{array}{l}\text { E.Angolense( } \\
\text { stem bark) }\end{array}$ & $\begin{array}{l}\text { K.Senegalen } \\
\text { sis(leaves) }\end{array}$ & $\begin{array}{l}\text { P.crassipes(l } \\
\text { eaves) }\end{array}$ & $\begin{array}{l}\text { A.leiocarpus(l } \\
\text { eaves) }\end{array}$ & $\begin{array}{l}\text { A.precatorius } \\
\text { (leaves) }\end{array}$ \\
\hline $\begin{array}{l}\text { Carbohydr } \\
\text { ate }\end{array}$ & + & - & + & - & - & - \\
\hline Alkaloids & - & - & - & - & - & - \\
\hline Tannins & + & + & + & + & + & + \\
\hline Glycosides & - & - & - & - & + & - \\
\hline Saponins & + & + & - & - & + & - \\
\hline Sterols & + & + & - & - & - & - \\
\hline Flavonoids & - & - & - & - & - & - \\
\hline Resins & - & - & - & - & - \\
\hline $\begin{array}{l}\text { Cardiac } \\
\text { glycosides }\end{array}$ & - & - & - & - & - & - \\
\hline Phenols & - & - & - & - & - & - \\
\hline Terpenoids & + & - & + & - & + & + \\
\hline Phlobatani & - & - & - & - & - & - \\
\hline
\end{tabular}




\begin{tabular}{|l|l|l|l|l|l|l|}
\hline ns & & & & & & \\
\hline Balsam & - & - & - & + & - & - \\
\hline Volatile oil & - & - & - & - & - & - \\
\hline $\begin{array}{l}\text { Anthracen } \\
\text { e }\end{array}$ & + & - & + & - & - & - \\
\hline $\begin{array}{l}\text { Anthraquin } \\
\text { one }\end{array}$ & - & - & - & - & - & - \\
\hline
\end{tabular}

$+=$ present $;$ - = absent

Table 2: \% of Inhibition at different concentrations $(\mathrm{mg} / \mathrm{ml})$ compared with Vitamin C.

\begin{tabular}{|l|l|l|l|l|l|l|}
\hline Plants & $0.05 \mathrm{mg} / \mathrm{ml}$ & $0.1 \mathrm{mg} / \mathrm{ml}$ & $0.5 \mathrm{mg} / \mathrm{ml}$ & $1 \mathrm{mg} / \mathrm{ml}$ & $2 \mathrm{mg} / \mathrm{ml}$ & $5 \mathrm{mg} / \mathrm{ml}$ \\
\hline E.angolense, RW & 81.34 & 80 & 75.31 & 67.46 & 55.21 & 21.63 \\
\hline E.angolense,SW & 84.02 & 82.68 & 81.44 & 80.96 & 76.08 & 70.34 \\
\hline K.senegalensis & 80.38 & 80.19 & 79.04 & 71.48 & 61.15 & 42.58 \\
\hline P.crassipes & 24.47 & 18.26 & 53.79 & 69.92 & 81.29 & 82.35 \\
\hline A.leiocarpus & 89.02 & 90.15 & 89.77 & 85.83 & 84.17 & 79.09 \\
\hline A.precatorius & 2.27 & 11.14 & 1.74 & 18.03 & 41.14 & 72.48 \\
\hline Vit.C(standard) & 90.19 & 90.32 & 91.32 & 91.50 & 91.41 & 85.00 \\
\hline
\end{tabular}

\section{CONCLUSION}

In the present study the antioxidant activity of five traditionally used medicinal plants were evaluated. The results of the present study suggest that tested plant materials have moderate to potent antioxidant activity and / or free radical scavenging activity. Nevertheless, the great antioxidant potential will be of immense benefit from the consumption of these medicinal plant/extracts. However, we do not know what components in the plant extracts show these activities. More detailed studies on chemical composition of the plant extracts, as well as other in vivo assays are essential to characterise them as biological antioxidants which are beyond the scope of this study. The findings of this study support the view that some medicinal plants are promising sources of potential antioxidant and may be efficient as preventive agent in some diseases. This providing data can just enrich the existing comprehensive data of antioxidant activity of plant material.

\section{ACKNOWLEDGEMENT}

We thank Mr. Adebisi Fagbohun for technical support and Mr.Jubril Akolade of the Biotechnology
Advanced Laboratory for his assistance in the preparation of this manuscript.

\section{REFERENCES}

Ayoola,G.A; Sofidiya T, Odukoya O, Coker H.A.B.(2006): Phytochemical Screening and free radical scavenging activity of some Nigerian medicinal plants. J.Pharm. Sci. \& Pharm. Pract.8: 133-136.

Beal, M.F. (1995): Aging, energy and oxidations stress in neurodegenerative diseases. Annals of Neurology; 38, 357-366.

Brand-Williams W, Cuvelier M.E.,Berset C. (1995):Use of free radical method to evaluate anti-oxidant activity. Lebensmittel wissenschaft und Technologie ,28, 2550 .

Buenz, I.F.F; Schenepple, D.J; and Motley, T.J. (2004) Technique: bio prospecting historical herbal texts by hunting for new leads in old tomes. Trends in pharmacological Sciences 25, 494-498.

Burkill,H.M.(1982): The useful plants of West Tropical, edition 2, vol.2,Pp 65-78, 345-387, 461-462.

Devasagayan, T.P.A; and Sainis, K.B. (2002): Immune system and anti -oxidants, especially those derived 
from Indian medicinal plants. Indian Journal of Experimental Biology, 40, 639-655.

Govindarajan , R; Vijayakumar, M; and Pushpangadan, P. (2005): Anti-oxidant approach to disease management and the role of ' Rasayana' herbs of Ayurveda. Journal of Ethnopharcology, 99, 165-178.

Javanraedi, J; Stushnoff, C; Locke, E; Vivanco, J.M ;( 2003): Antioxidant activity and total phenolic content of Iranian Ocimum accessions, Food Chem. 83, 547-550.

Kahkonen ,M.P; Hopia, A.I; Vuroela, H.J; Rauha, J.P; Pihlaja, K; Kujala, T.S; et. al (1999): Anti-oxidant activity of plant extracts containing phenolic compounds. Journal of Agricultural and Food Chemistry, 47, 3954-3962. Larson, R.A. (1988): The anti-oxidants of higher plants. Phytochemistry, 27, 969-978.
Maxwell, S.R.J. (1995): Prospects for the use of antioxidant therapies, Drugs, 45, 345-361.

Park, E.J. and Pezzutto, J.M. (2002): Botanicals in Cancer Chemo preventives. Cancer and Metastasis Reviews, 21, 231-255.

Polterait O. (1997): Antioxidants and free- radical scavengers of Natural Origin. Current Org.Chem.,1: 415-440.

Poulson, Preime, H and Loft, S.(1998): Role of oxidative DNA damage in cancer initiation and promotion. European Journal of Cancer Preventive, 7, 9-16.

Trease, G.E. and Evans, W.C. pharmacognosy. $13^{\text {th }}$ edn. Bailliere Tindall. 